\title{
A GIS-based Distributed Parameter Model for Rainfall Runoff Calculation using Arc Hydro Tool and Curve Number Method for Chikugo River Basin in Japan
}

Chinh, Le Van

Laboratory of Water Environment Engineering, Division of Bioproduction Environmental Sciences, Department of Agro-environmental Sciences, Faculty of Agriculture, Kyushu University

Iseri, Haruka

Laboratory of Water Environment Engineering, Division of Bioproduction Environmental Sciences, Department of Agro-environmental Sciences, Faculty of Agriculture, Kyushu University

Hiramatsu, Kazuaki

Laboratory of Water Environment Engineering, Division of Bioproduction Environmental Sciences, Department of Agro-environmental Sciences, Faculty of Agriculture, Kyushu University

Harada, Masayoshi

Laboratory of Water Environment Engineering, Division of Bioproduction Environmental Sciences, Department of Agro-environmental Sciences, Faculty of Agriculture, Kyushu University

https://doi.org/10.5109/18847

出版情報: 九州大学大学院農学研究院紀要. 55 (2)，pp.313-319，2010-10-29. 九州大学大学院農学研究 院 バージョン：

権利関係 : 


\title{
A GIS-based Distributed Parameter Model for Rainfall Runoff Calculation using Arc Hydro Tool and Curve Number Method for Chikugo River Basin in Japan
}

\author{
Le Van CHINH ${ }^{*}$, Haruka ISERI, Kazuaki HIRAMATSU \\ and Masayoshi HARADA
}

\author{
Laboratory of Water Environment Engineering, Division of Bioproduction Environmental Sciences, \\ Department of Agro-environmental Sciences, Faculty of Agriculture, \\ Kyushu University, Fukuoka 812-8581, Japan \\ (Received June 28, 2010 and accepted July 9, 2010)
}

\begin{abstract}
Determination of peak and total runoff due to rainfall is the most important for watershed management and designing hydraulic structures. The measurement of runoff is always the best way but it is not possible at desired time and location. A rainfall runoff modeling, which uses geographical information system (GIS) data based, is a convenient and powerful tool to solve the above mentioned complexities. This technology was applied in this study in order to simulate the runoff discharge in the Chikugo River basin in Kyushu Island, Japan. First, an extension tool (Arc Hydro) of a GIS software was used for simulations of elevation, drainage line definition, watershed delineation, drainage feature characterization, and geometric network generation. Second, the spatial distribution of land-cover, soil classification, and rainfall were analyzed for calculating the rainfall excess distribution in the basin. An important point of this approach is that the spatially distributed rainfall excess volume was computed by the Natural Resources Conservation Service Curve Number (NRCS-CN) method. The final goal of this study is a total discharge volume in the sub-watershed region of the basin was consequently computed on a monthly basis throughout one year (from April 2005 to March 2006) by using NRCS-CN model. The results show that the simulated stream network was totally consistent with its existing one. Additionally, the observed and simulated runoff discharges were in good agreement, indicating that the proposed model is applicable for rainfall runoff analyses in this river basin. For further, this model will be able to provide managers and operators a useful tool that is to optimize the water surface management in the Chikugo River basin.
\end{abstract}

Keywords: Rainfall runoff, River Basin, GIS, discharge, stream network, curve number, simulation

\section{INTRODUCTION}

Runoff is one of the most important hydrologic variables used in most of water resources applications. Reliable prediction of quantity and rate of runoff from land surface into streams and rivers is difficult and time consuming to obtain for ungauged watersheds (Nayak and Jaiswal, 2003). In several decades, the lumped watershed models have been used traditionally to analyze the conversion excess rainfall into surface runoff. These models typically assume that excess rainfall and hydrologic parameters are uniform over the watershed and that the rainfall runoff process is linear and can be predicted using hydrograph theory (Melesse et al., 2003). However, in practice, the excess rainfall and hydrologic parameter are non uniform over large watershed. To overcome this deficiency, spatially distributed models have developed (Ott, et al., 1991; Olivera and Maidment, 1999) in which the watershed is divided into a number of sub-watersheds or cells with spatially variable excess rainfall and hydrologic parameters. Distributed-parameter models divide the entire watershed into smaller sub-basins or grids which are assumed to have uniform hydrologic char-

\footnotetext{
Laboratory of Water Environment Engineering, Division of Bioproduction Environmental Sciences, Department of Agroenvironmental Sciences, Faculty of Agriculture, Kyushu University

* Corresponding author (E-mail: chinhhec1@yahoo.com)
}

acteristics. Distributed parameter model may be more accurate since they offer the possibility of modeling the spatial variability of hydrologic parameters. Moreover, in flood prediction and rainfall runoff computation physically based distributed modeling of watershed processes has become increasingly feasible in recent years. In addition to the development of improved computational capabilities, Digital Elevation Model (DEM), digital data of soil type and land-use, as well as the tool of Geographical Information System (GIS), give new possibilities for hydrologic research in understanding of the fundamental physical process underlying the hydrologic cycle and of the solution of mathematical equations representation those processes (Liu et al., 2003). Actually, GIS is a computer-based tool that displays, stores, analyzes, retrieves and generates spatial and non-spatial (attribute) data. GIS technology is a well-established tool used in hydrologic modeling, which facilities processing, management and interpretation of all available data. It also provides a practical means for modeling and analyzing the spatial characteristic of the hydrologic cycle.

Therefore, many studies have been done to incorporate GIS in hydrologic model of watersheds. Typical examples are the following works. Maidment (1992a and 1992b) introduced a procedure using raster GIS and a time-area method to drive a spatially distributed unit hydrograph. Maidment used the Digital Elevation Model (DEM) of watershed to determine the flow direction from each cell based on the maximum downhill slope, runoff 
discharge, and flow velocity. Zhan and Huang (2004) developed the application of ArcCN-Runoff tool to determine curve number and calculate runoff or infiltration for rainfall event in a watershed. Zhan and Huang also pointed that (NRCS-CN) method is the most common and popular method for estimating surface runoff and peak discharge in depth from rainfall event. In this model, curve number (CN) was regarded as the representative of single parameter to express water retention in soil. Values for soil retention are estimated from various correlations of many factors influencing infiltration, rainfall pattern, initial soil moisture, tillage practice, physical soil properties and densities of vegetation roots and stems. Factors of surface roughness, surface storage, slope, size of watershed overland flow area, as well as rate of precipitation have also been taken into account in the model (Mack, 1995). Therefore, selection of curve numbers, which vary with soil type, land use cover and hydrologic condition of the soil, plays a vital role in the CN model. Elizabeth et al. (2008) also used GIS based data incorporated with (NRCS-CN) method to estimate both the event storm and peak runoff rate.

In the present study, an application for rainfall runoff model in the Chikugo River Basin in Kyushu Island, Japan was carried out by using an extension tool (Arc Hydro) of a well-know GIS software (ArcGIS) incorporated with the Natural Resources Conservation Service Curve Number (NRCS-CN) method. The elevation, drainage line definition, watershed delineation, drainage feature characterization, and geometric network generation were simulated as well as spatial distribution of landcover, soil classification, and rainfall. Next, the surface runoff in the sub-watershed region of the basin was computed on a monthly basis throughout one year (from April 2005 to March 2006) then the simulated results of the model were evaluated by comparing with those observed ones. Grid operation together with curve number and runoff models used in this study will be clearly presented.

\section{MATERIALS AND METHODS}

\section{Study area}

Chikugo River basin, which is located in Kyushu Island in Japan, belongs to Oita, Fukuoka, Kumamoto, and Saga prefectures as shown in Fig. 1. It is mainly covered with forest, wetlands, agriculture, and urban-built up areas. The total basin area is about $2,800 \mathrm{~km}^{2}$. The Chikugo River rises under the Mount Aso, and discharges into the Ariake Sea. With a total length of 143 kilometers, it is the longest river of Kyushu Island. The upper reaches of the river are important to forestry, whereas the middle and lower reaches are important to local agriculture, providing irrigation to some $400 \mathrm{~km}^{2}$ of rice fields on the Tsukushi Plain. The river is also important to industry, with twenty electrical power plants are located along the banks of the Chikugo River, as well as the major city of Kurume in Fukuoka prefecture.

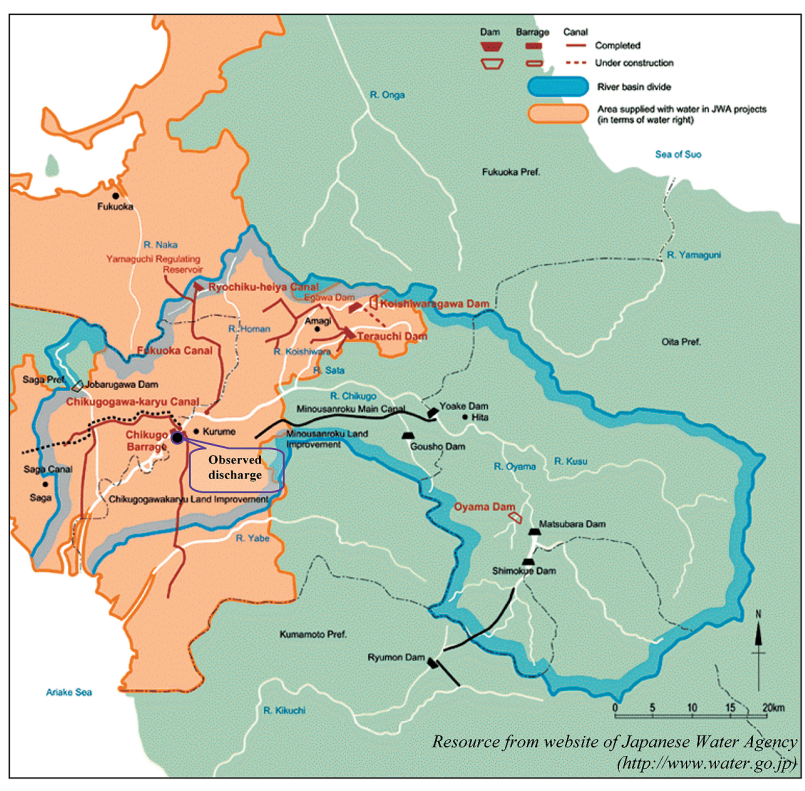

Fig. 1. Location of Chikugo River basin.

\section{Data}

The data used as initial input in this study were obtained from the two main important recourses: DEM and flow line maps. These data, as well as soil and landuse maps, were provided by the Ministry of Land, Infrastructure, and Transportation (MLIT). The hourly rainfall series, which have been observed in the Chikugo Barrage sub-watershed, were used for simulating the runoff discharge. Additionally, in order to evaluate the applicability of the proposed model in the present study, daily discharge have been observed at the Chikugo Barrage from April 2005 to March 2006, were used for the verification of the proposed model. These hydro-Metrological data were supplied from Fukuoka Prefecture Government. The observed discharge point is shown in Fig. 1.

\section{Digital Elevation Model (DEM)}

DEMs were used to determine the hydrologic parameters such as slope, flow accumulation, flow direction, drainage area delineation, and stream network. The resolution of DEM affects the results of watershed delineation and stream definition (Luzio et al, 2005). Thus, in order to obtain a better output and eliminate some unpredicted error, a highest resolution DEM $(50 \times 50 \mathrm{~m})$ was

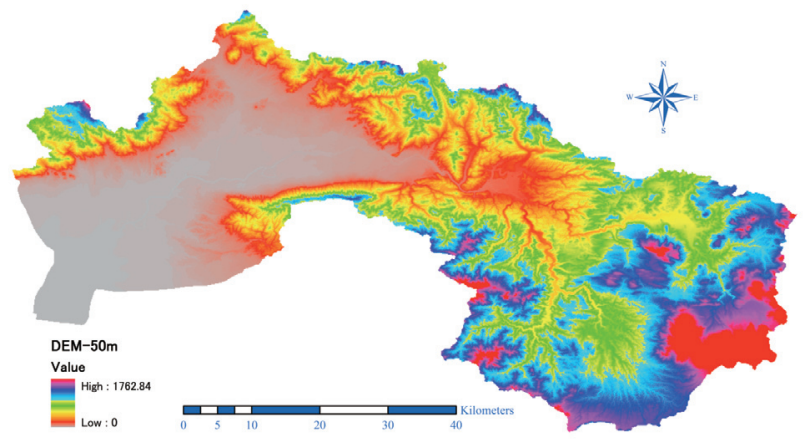

Fig. 2. 50-m DEM of Chikugo River basin. 


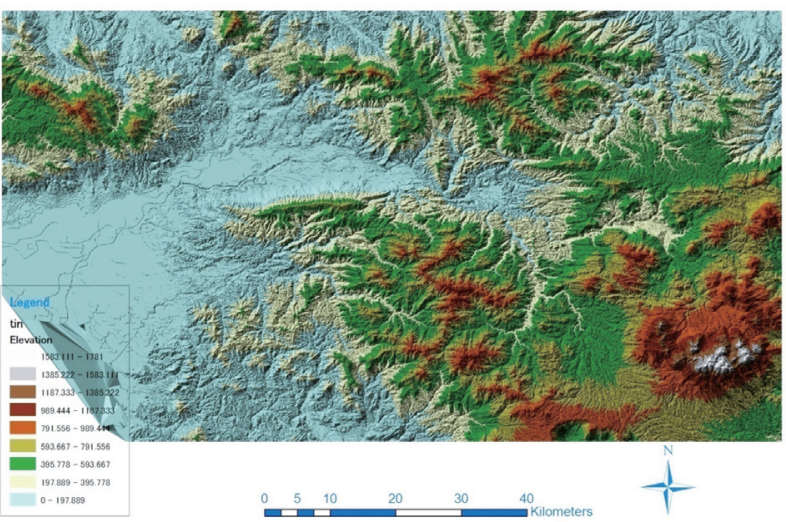

Fig. 3. Triangal irrigular network of Chikogo River basin.

adopted. The elevation data involved in the DEM was initially obtained by interpolating the official elevation data from MLIT using the Kriging method (Fig. 2). The triangulated irregular network was also generated by ArcGIS tool for better view and analysis, as presented in Fig. 3.

\section{Drainage analysis using digital elevation models} Flow direction grid:

Water in a given cell can flow to one or more of its eight adjacent cells according to the slopes of the drainage paths. This concept is called the eight-direction pour point model. There are several variants of the eightdirection pour point model, but the simplest, and the one used in ArcGIS, allows water from a given cell to flow into only one adjacent cell, along the direction of steepest descent (Maidment, 2002). The result flow direction was encoded 1 for east, 2 for southeast, 4 for south, 8 for southwest, 16 for west, 32 for northwest, 64 for north, and, finally 128 for northeast (Fig. 4).

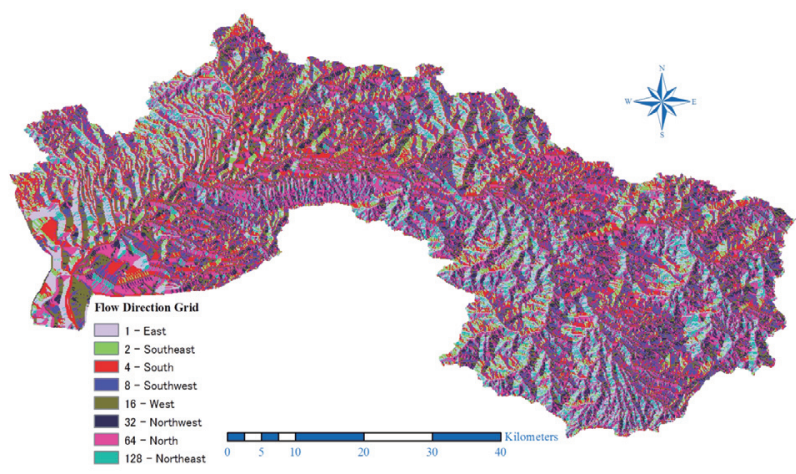

Fig. 4. Flow direction grid of Chikugo River basin (eight-direction pour point method).

\section{Flow accumulation grid:}

Flow accumulation was calculated from the flow direction grid. The flow direction grid recoded the number of cells that drained into individual cell in the grid. Therefore, from the physical point of view, the flow accumulation grid is the drainage area measured in units of grid cells. The flow accumulation grid of the Chikugo River basin was depicted in Fig. 5.

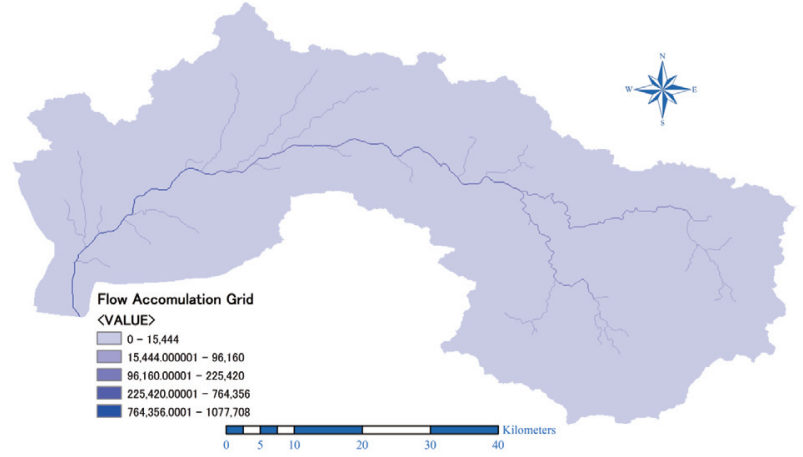

Fig. 5. Flow accomulation grid of Chikugo River basin.

Stream definition using a threshold drainage area:

With a flow accumulation grid, streams may be defined through the use of a threshold drainage area or flow accumulation value (Maidment, 2002). This study used the standard value for stream definition of Arc Hydro tools, which is $1 \%$ of the maximum flow accumulation of the basin. Smaller threshold will results denser stream network and usually lower speed of catchment's delineating process. In this case, $1 \%$ of the outlet point of 1077,708 cells is equivalent to $27 \mathrm{~km}^{2}$ the drainage areawidth $50 \mathrm{~m} \times 50 \mathrm{~m}$ for each cell size. All drainage points with smaller area than $27 \mathrm{~km}^{2}$ would not be considered as stream cells and identically with a value of 0 rather than 1 . Consequently, the whole created stream network was then divided into distinct stream segments with unique code numbers. These stream segments are called "stream links" (ESERI, 2003)

\section{Catchment delineation:}

To define catchments for each stream link, the flow direction grid are used for separating the zone of cell whose drainage flows through each stream link. The results of the delineation are stored in a catchment grid, and identically labeled exactly as its stream link's code (Maidment, 2002). Base on that, the catchment polygons could be converted using Arc Hydro tool (Fig. 6).

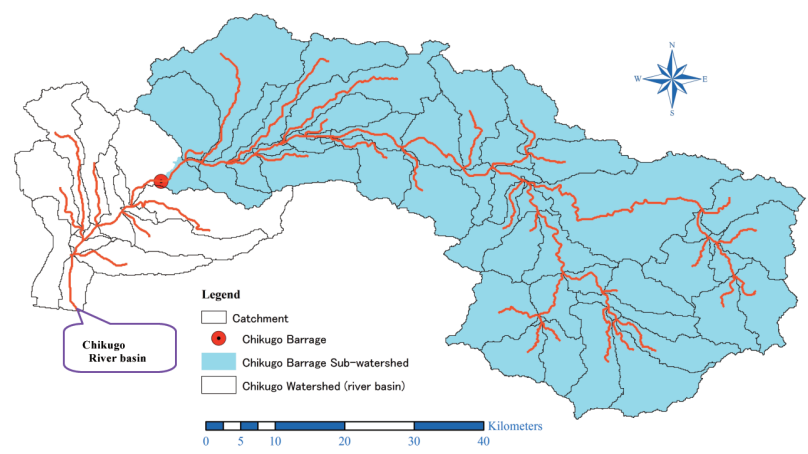

Fig. 6. Watershed, sub-watershed, and catchment boundaries.

\section{Watershed delineation:}

Catchment processing from DEM is preliminary or preprocessing step to watershed delineation using the 
Arc Hydro watershed processing tools. The standard application for watershed delineation is to identify a series of points on the hydro network as watershed outlets, then divide and merge the underlying catchment to produce sub-watershed. There are two alternatives: to produce watersheds or to produce sub-watersheds. When producing watershed with Arc Hydro toolset, the result is a watershed polygon for each outlet point that covers its entire upstream drainage area. Whereas, producing sub-watersheds results in a polygon for each outlet point that covers only the incremental drainage area upstream of this outlet point and downstream of all others. In this study, a representative of outlet point of the Chikugo River basin was processed together with a point in the Chikugo Barrage sub-watershed (Fig. 6). The computation of runoff, which included the spatially distributed hydrologic parameters and (NRCS-CN) method analysis, focused mainly on the Chikugo Barrage sub-watershed.

\section{Curve number and runoff model}

In the early 1950's, the United States Department of Agriculture (USDA) NRCS (then named Soil Conservation Service, SCS) developed a method for estimating the volume of direct runoff from rainfall. This method, which is often referred to as the curve number method, was empirically developed for watersheds. Analysis of storm event rainfall and runoff records indicates that there is a threshold which must be exceeded before runoff occurs. The storm must satisfy interception, depression storage, and infiltration volume before the onset of runoff. The rainfall required to satisfy the above volumes is termed initial abstraction. Additional losses as infiltration will occur after runoff begins. After runoff begins, accumulated infiltration increases with increasing rainfall up to some maximum retention. Runoff also increases as rainfall increases. The ratio of actual retention to maximum retention is assumed to be equal to the ratio of direct runoff to rainfall minus initial abstraction. This can be expressed mathematically as (USDA, 1985)

$$
\frac{F}{S}=\frac{Q}{P-I}
$$

In equation (1), $F$ is actual retention after runoff begins, $\mathrm{mm}$; $S$ is watershed storage, $\mathrm{mm}$; $Q$ is actual direct runoff, mm; $P$ is total rainfall, $\mathrm{mm}$; $I$ is initial abstraction, $\mathrm{mm}$.

The amount of actual retention can be expressed as

$$
F=(P-I)-Q
$$

The initial abstraction defined by the NRCS mainly consists of interception, depression storage, and infiltration occurring prior to runoff. To eliminate the necessity of estimating both parameters $I$ and $S$ in the above equation, the relation between $I$ and $S$ was estimated by analyzing rainfall runoff data for many small watersheds. The empirical relationship is

$I=0.2 S$

Substituting Eq. 3 into Eq. 1 and 2 yields

$$
\begin{array}{lll}
Q=\frac{(P-0.2 S)^{2}}{P+0.8 S} & \text { if } \quad P>0.2 S \\
Q=0 & \text { if } \quad P \leq 0.2 S
\end{array}
$$

Which is the rainfall-runoff equation used by the NRCS for estimating depth of direct runoff from storm rainfall. The equation has one variable $P$ and one parameter $S$. $S$ is related to curve number $(C N)$ by

$$
S=\frac{25400}{C N}-254
$$

where $C N$ is a dimensionless parameter and its value range from 1 (minimum runoff) to 100 (maximum runoff). It is determined based on the following factors: hydrologic soil group, land-use, land treatment, and hydrologic conditions. The NRCS runoff equation is

\begin{tabular}{|c|c|c|}
\hline Soil group & Description & $\begin{array}{l}\text { Final } \\
\text { infiltration rate } \\
(\mathrm{mm} / \mathrm{hr})\end{array}$ \\
\hline A & $\begin{array}{l}\text { Lowest runoff potential. Includes deep sands with very little silt and clays, also deep, } \\
\text { rapidly permeable loess. }\end{array}$ & 8-12 \\
\hline B & $\begin{array}{l}\text { Moderately low runoff potential. Mostly sandy soils less deep than A, and less deep or } \\
\text { less aggregated than A, but the group as a whole has above average infilteration } \\
\text { thorough wetting. }\end{array}$ & $4-8$ \\
\hline $\mathrm{C}$ & $\begin{array}{l}\text { Moderately high runoff potential. Comprises shallow soils and soils containing } \\
\text { considerable clay and colloids, though less than those of group D. The group has } \\
\text { below-average infilteration after presaturation. }\end{array}$ & $1-4$ \\
\hline D & $\begin{array}{l}\text { Highest runoff potential. Includes mostly clays of high swelling percent, but the } \\
\text { group also includes some shallow soils with nearly impermeable subhorizones near } \\
\text { the surface. }\end{array}$ & $0-1$ \\
\hline
\end{tabular}
widely used in estimating direct runoff because of its simplicity and flexibility.

Finally, the basic equation (4) was combined with

Table 1. Hydrologic soil group descriptions (from USDA, 1985) (see also Fig. 7) 
the spatially distributed parameters of soil, land-use, and rainfall in order to simulate the runoff in the Chikugo Barrage sub-watershed. The total monthly discharge was computed by following equation:

$$
Q_{\text {month }(i)}=\sum_{j=1}^{n} Q_{i j} \times A_{j}
$$

where $\mathrm{Q}_{\text {month }(i)}$ is the total monthly runoff discharge of the sub-watershed in month $i, \mathrm{~m}^{3} ; Q_{i j}$ is depth of direct runoff in month $i$ of cell No. $j, \mathrm{~m} ; A_{j}$ is the area of corresponding cell No. $j, \mathrm{~m}^{2}$; and $n$ is total cell numbers of the sub-watershed.

\section{Hydrologic soil group classification}

Soils were classified into four hydrologic soil groups (A, B, C, and D) according to their minimum infiltration rate. A description of these groups is shown in Table 1. Base on that, the classification of hydrologic soil groups of the Chikugo Barrage sub-watershed was visualized in

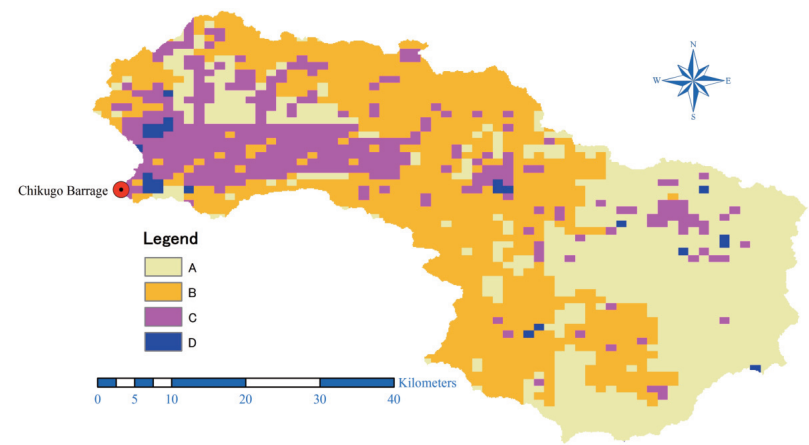

Fig. 7. Hydrologic soil group of Chikugo Barrage sub-watershed (see also Table 1).
Fig. 7.

\section{Combination of hydrologic soil group and land-use classes}

Land-use data was also classified into nine classes (Fig. 8). This spatially distributed parameter was combined with the hydrologic soil group classification in order to determine the value of $C N$ that was mentioned above (Eq. 5). Chow et al. (1988) introduced a relationship between land cover and hydrologic soil group, as presented in Table 2.

\section{Spatially distributed rainfall}

There are several methods of determining weighting coefficients for the spatial distribution of rainfall, and all of them yield slightly different variations of rainfall patterns across an area. The Thiessen method is a widely recognized scheme proven to be reasonably accurate at estimating areal precipitation distributions, and so was

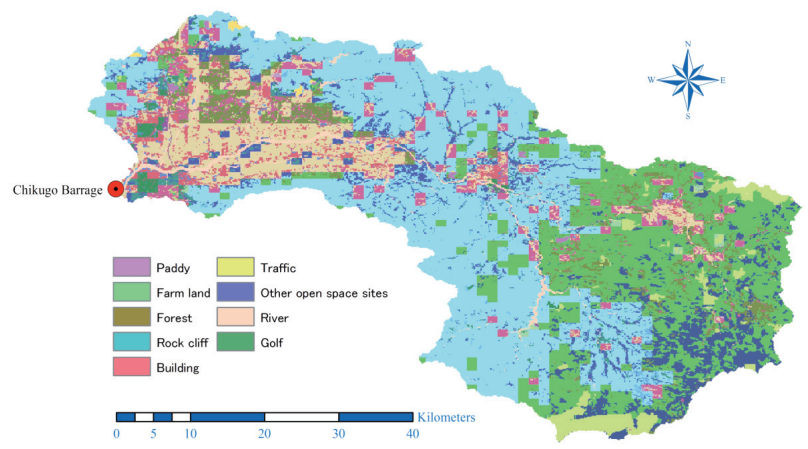

Fig. 8. Land-use classification of Chikugo Barrage sub-watershed.

Table 2. Table of runoff curve number

\begin{tabular}{lrrrr}
\hline \multirow{2}{*}{ Description of land-use } & \multicolumn{4}{c}{ Hydrologic soil group } \\
\cline { 2 - 6 } & A & B & C & D \\
\hline Cultivated (Agricultural Crop) Land: & & & & \\
Without conservation treatment (no terraces) & 72 & 81 & 88 & 91 \\
With conservation treatment (terraces, contours) & 62 & 71 & 78 & 81 \\
Woods and Forests: & & & & \\
Poor (small trees/brush destroyed by over-grazing or burning) & 45 & 66 & 77 & 83 \\
Fair (grazing but not burned; some brush) & 36 & 60 & 73 & 79 \\
Good (no grazing; brush covers ground) & 30 & 55 & 70 & 77 \\
Residential Areas: & & & & \\
1/8 Acre lots, about 65\% impervious & 77 & 85 & 90 & 92 \\
1/4 Acre lots, about 38\% impervious & 61 & 75 & 83 & 87 \\
1/2 Acre lots, about 25\% impervious & 54 & 70 & 80 & 85 \\
1 Acre lots, about 20\% impervious & 51 & 68 & 79 & 84 \\
Streets and Roads: & & & & \\
Paved with curbs and storm sewers & 98 & 98 & 98 & 98 \\
Gravel & 76 & 85 & 89 & 91 \\
Dirt & 72 & 82 & 87 & 89 \\
Open Spaces (lawns, parks, golf courses, cemeteries, etc.): & & & & \\
Fair (grass covers 50-75\% of area) & 49 & 69 & 79 & 84 \\
Good (grass covers $>$ 75\% of area) & 39 & 61 & 74 & 80 \\
Open water & 0 & 0 & 0 & 0 \\
\hline
\end{tabular}


the method of choice in this study. The primary assumption in the Thiessen method is that areas closest to a precipitation station are most likely to experience similar rainfall conditions to those measured at the station location (Chow et al., 1988).

The hourly rainfall series, which have been observed in the Chikugo Barrage sub-watershed, were used for simulating the runoff discharge. Using the eight nearest rainfall gages to the Chikugo Barrage sub-watershed, Thiessen polygons (Fig. 9) were constructed using the GIS to determine the spatial distribution of storms for computation of spatially variable excess rainfall.

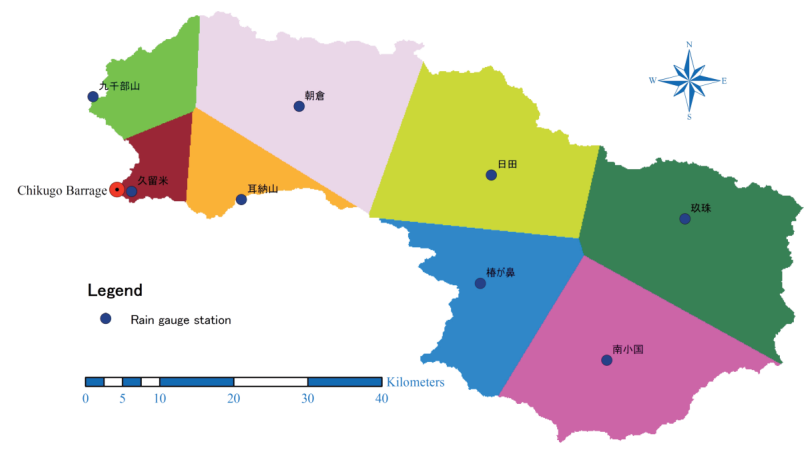

Fig. 9. Thiessen polygons for Chikugo Barrage sub-watershed.

\section{RESULTS AND DISCUSSION}

\section{Evaluation of the simulated stream network}

First, the accuracy of the proposed model was evaluated by comparing the simulated stream network with the existing flow lines. Figure 10 displays a stream network derived automatically from DEM computation and a manual operation using topographic maps. The results show that the simulated drainage networks were totally consistent with the actual flow lines that were obtained from data resources of MLIT. This indicated that the proposed model is applicable for generating the stream network.

In this simulation, the drainage line extracted from DEM was divided into 64 stream segments, which responded to 64 numbers of sub-catchments in the basin.

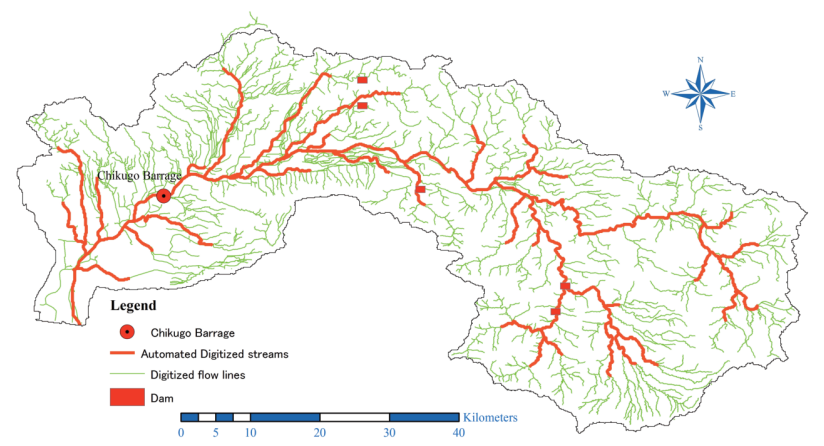

Fig. 10. Automated digital streams and digitized flow lines.
Each stream segment carries a grid ID and a drain ID, as shown in Fig. 11.

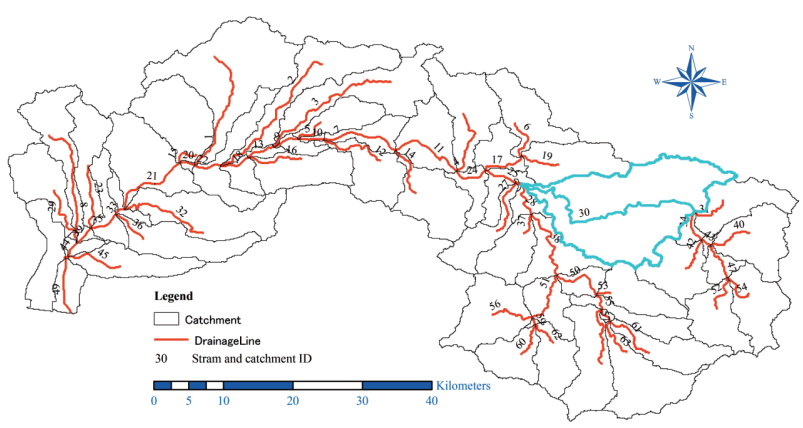

Fig. 11. Stream segments and catchments.

The powerful and convenient point of this simulation is that we could delineate any interest sub-watersheds, catchments, and streams by extract tool in order to analyze the runoff discharge or flow parameters at their outlet or inlet points. In this study, the Chikugo Barrage sub-watershed was delineated and extracted for analyzing and simulating the runoff discharge at the Chikugo Barrage outlet.

\section{Comparison of observed and simulated discharge at the Chikugo Barrage station}

The NRCS-CN runoff model has proved to be ideally acceptable for surface discharge calculation. In this approach, runoff volume using the NRCS-CN method (infiltration excess) at the Chikugo Barrage was estimated. The Chikugo Barrage sub-watershed was divided into eight rainfall areas. Weights were assigned according to area of Thiessen polygons falling in each area and the weighted average monthly rainfall was calculated for the eight areas.

As shown in Fig. 12, the monthly simulated discharges are in good agreement with those observed ones throughout one year. The figure also well expresses correspondence of each discharge with fluctuating amount of rainfall within the year. The simulated peak runoff discharge obtained about $1020.10^{6} \mathrm{~m}^{3}$ in July 2005 due to the average rainfall of this month was maximum depth (700 mm) during the simulation period. The relationship between the monthly simulated direct surface runoff and

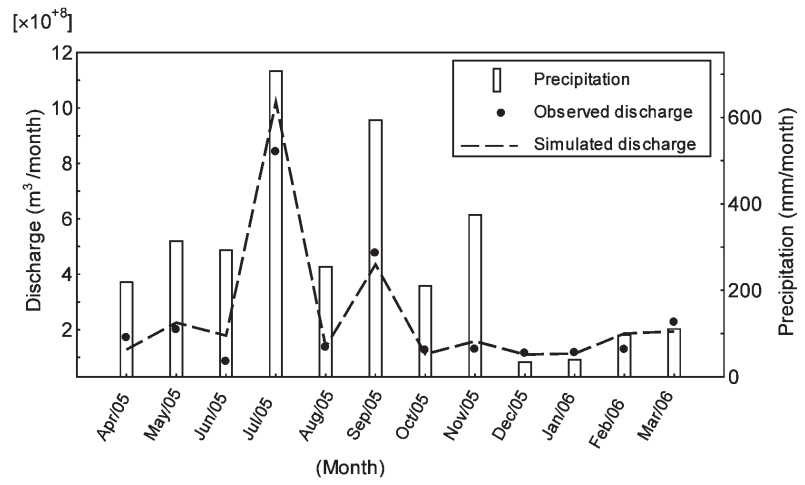

Fig. 12. Simulated and observed runoff discharges at the Chikugo Barrage - 2005 . 


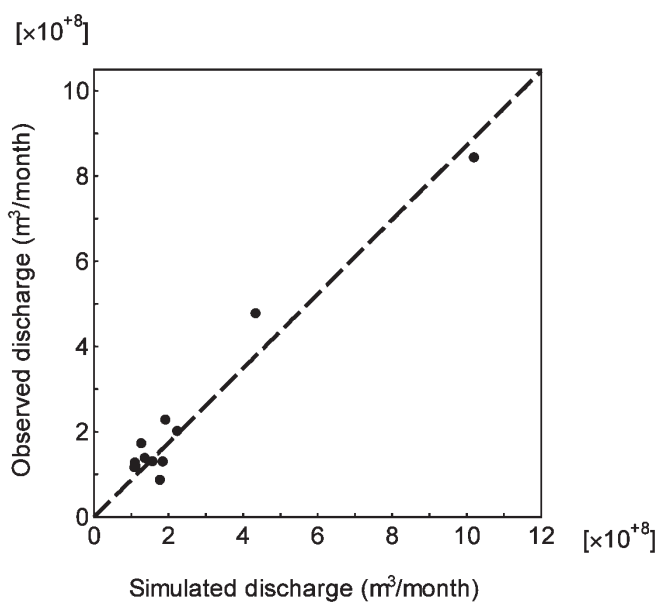

Fig. 13. The relationship of simulated and observed runoff discharges.

observed ones was depicted in Fig. 13. The correlation between them is equivalent to 0.97 . Therefore, we can confirm that in general good correlation has been found between monthly observed and simulated runoff discharge.

\section{For further study}

The target for further study is the hourly or daily runoff hydrograph at the outlet of the Chikugo Barrage subwatershed. These simulated results may be obtained from determining abstractions of land-cover, soils and rainfall information, followed by routing the spatially distributed runoff using topographic data. Spatially distributed direct hydrographs may be generated using the concept of travel time distribution. Therefore, the key point in this approach is to determine the flow velocity of overland cells and channel cells. Incorporated with ArcGIS software, the combination of a kinetic wave approximation with Manning's equation or continuity equation may solve the above problems in further study.

\section{Conclusion}

This paper presented a rainfall runoff model in the Chikugo River basin that mixtures forest, agricultural lands, and urban areas, for simulating stream network and calculating the direct runoff discharge. First, Arc Hydro GIS interface software was used to simulate and delineate the watershed. A digital elevation model (DEM) was primarily taken into account to reduce errors due to input data with low quality and naturally unavoidable mistakes of the program operation. Then the flow direction grid, flow accumulation grid, and stream network could be generated automatically. The results show that the simulated stream network and its actual one are in good agreement. Second, the monthly direct discharge runoff at the Chikugo Barrage was simulated by using the NRCS-CN runoff method incorporated with the spatially distributed parameters of land-use/cover and soil classes, and rainfall. The correlation between the simulated and observed monthly runoff discharge was estimated. A good correlation was found between observed and simu- lated. Therefore we can conclude that the proposed model was applicable for rainfall runoff analyses in this river basin. The important goal of the present study is that the applied model will be able to provide managers and operators a useful tool that is to optimize the water surface management in the Chikugo River Basin.

\section{ACKNOWLEDGEMENTS}

The authors wish to acknowledge the Ministry of Land, Infracstructure, and Transportation of Japan for poviding the GIS data resources. We appreciate the helpful of Fukuoka Prefecture Government for the acquisition of the measurement of hydro-Metrological data.

\section{REFERENCES}

Chow, V. T., D. R. Maidment and L. W. Mays 1988 Applied of Hydrology. McGraw-Hill Inc., New York

Elizabeth, N. M., N. S. Levine and D. M. Amatya 2008 Rainfallrunoff modeling of Chapel Branch Creek watershed using GIS-based rational and SCS-CN method. ASABE meeting presentation, paper No. 83971

ESRI 2003 Arc Hydro Tool-Tutorial, Version 1.1 Beta 2, pp. $14-50$

Liu, Y. B., S. Gebremeskel, F. D. Smedt, L. Hoffmann and L. Pfister 2003 A diffuse transport approach for flow routing in GISbased flood modeling. Journal of Hydrology, 283: 91-106

Luzio, M. D., J. G. Arnold and R. Srinivasan 2005 Effect of GIS data quality on small watershed stream flow and sediment simulation. Hydrology Process, 19: 629-650

Mack, M. J. 1995 Her-Hydrologic evaluation of runoff; the soil conservation service of curve number runoff technique as an interactive computer model. Computers and Geosciences, 21(8): 929-935

Maidment, D. R. $1992 \mathrm{a}$ Grid-Based Computation of Runoff. A Preliminary Assessment, Hydrologic Engineering Center, US Army Coprs of Engineers, Davis, California, Contract DACW05-92-P-1983

Maidment, D. R. $1992 \mathrm{~b}$ Grid-Network Procedure for Hydrologic Modeling. Hydrologic Engineering Center, US Army Coprs of Engineers, Davis, California, Contract DACW05-92-P-1983

Maidment, D. R. 2002 Arc Hydro: GIS for Water Resources. ESRI Press, Redland (CA) pp. 56-86

Melesse, A. M., W. D. Graham and J. D. Jordan 2003 Spatially distributed watershed mapping and modeling: GIS-based storm runoff response and hydrograph analysis: part 2 Journal of Spatial Hydrology, 3(2): 1-27

Nayak, T. R. and R. K. Jaiswal 2003 Rainfall-runoff modeling using satellite data and GIS for Bebas River in Madhya Pradesh. The India Institution of Engineer Journal, 84: 47-50

Olivera, F. and D. R. Maidment 1999 Geographic Information System (GIS)-based spatially distributed model for runoff routing. Water Resources Res, 35: 1155-1164

Ott, M., Z. Su, A. H. Schumann and G. A. Schultz 1991 Development of a distributed hydrological model for flood forecasting and impact assessment of land-use change in the international Mosel River basin. Hydrology for Water Management of Large River Basins, Proc. Of Vienna Symposium. IAHS Pub. No. 201

USDA, Soil conservation Service 1985 National Engineering Handbook, section 4: Hydrology. U.S. Government Printing Office, Washington, DC

Zhan, X. and M. L. Huang 2004 ArcCN-Runoff: an ArcGIS tool for generating curve number and runoff maps. Environment Engineering and Software, 19: 875-879 